\title{
Hubungan Aktivitas Bermain Dengan Kemampuan Motorik Siswa Sekolah Dasar Negeri 11 Padang Barat
}

\author{
Rama Afrengty ${ }^{1}$, Eldawaty ${ }^{2}$, Aldo Naza Putra ${ }^{3}$ \\ ${ }^{123}$ Fakultas Ilmu Keolahragaan, Universitas Negeri Padang, Indonesia. \\ E-mail: frengty@yahoo.co.id ${ }^{1}$, eldawaty@fik.unp.ac.id ${ }^{2}$, aldonazaputra@fik.unp.ac.id ${ }^{3}$
}

\begin{abstract}
Abstrak
Masalah penelitian adalah rendahnya kemampuan motorik siswa untuk melihat kemungkinan factor-faktor penyebab rendahnya kemampuan motorik siswa ini, maka dilakukan suatu penelitian yang bertujuan untuk mengetahui seberapa besar hubungan antara aktivitas bermain dengan kemampuan motorik . Khususnya siswa di Sekolah Dasar Negeri 11 Padang Barat Kota padang.

Penelitian ini tergolong pada jenis penelitian korelasional atau menggunakan teknik korelasional.Populasi adalah seluruh siswa SD Negeri 11 Padang Barat yang berjumlah sebanyak 180 orang. Sample diambil dengan teknik purposive sampling, dengan demikian jumlah sample dalam penelitian ini adalah 29 orang.Jenis data dalam penelitian ini yaitu data primer a) Pengamatan langsung kepada siswa untuk memperoleh gambaran tentang aktivitas bermain yang dilakukan pada saat jam istirahat disekolah dan b) Hasil pengukuran tes kemampuan motorik.

Hasil analisis data menunjukan bahwa aktivitas bermain (X) dengan kemampuan motorik (Y) siswa putera menunjukan hubungan yang signifikan. Besarnya sumbangan aktivitas bermain terhyadap kemampuan motorik siswa putera sebesar $59.29 \%$. Sedangkan untuk aktivitas bermain dengan kemampuan motorik siswa puteri menunujukan hubungan yang signifikan dan besarnya sumbangan aktivitas bermain terhadap kemampuan motorik siswa puteri adalah sebesar 53.35\%.
\end{abstract}

Kata Kunci: Aktivitas Bermain, Kemampuan Motorik.

\section{Abstract}

The problem of research is the low motor ability of the students to see the possible factors causing low motor capability of this student, then conducted a study aimed at knowing how much the relationship between playing activities with motor ability. Especially for students in Negeri 11 West Padang Barat Elementary School.

This research belongs to the type of correlational study or using correlational technique. The population is the total elementary school students of 11 West Padang, amounting to 180 people. Samples were taken with purposive sampling techniques, thus the number of samples in this study was 29 people. The type of data in this study is primary data a) direct observation to the students for an overview of playing activities performed during the rest hours in the school and b) test results of motor capability tests.

Data analysis results show that playing activity $(X)$ with motor capability $(Y)$ The son of the children showed significant relationship. The contribution of the children's motor skills has been reduced by 59.29\%. As for the playing activity with the motor skills of the daughter students to show a significant relationship and the amount of donation activity playing against the motor skills of the daughter students is $53.35 \%$.

Keywords: Play activity, Motor capability.

\section{PENDAHULUAN}

Sekolah dasar (SD) merupakan salah satu lembaga pendidikan yang memberikan bekal kepada siswa untuk melanjutkan pendidikan nya ke jenjang yang lebih tinggi. Mata pelajaran yang tercantum 
Sport Science: Jurnal Sain Olahraga dan Pendidikan Jasmani ISSN 114-562X (Cetak), ISSN XXXX-XXXX(Online)

http://sportscience.ppj.unp.ac.id/index.php/jss/index

dalam kurikulum SD dapat dikelompokan : Program pendidikan Umum, Program Pendidikan Akademis dan Program pendidikan Keterampilan. Diantara Mata pelajaran program pendidikan umum adalah mata pelajaran pendidikan jasmani,olahraga dan kesehatan ( Penjasorkes). Luthan (2001:5) mengatakan bahwa pendidikan jasmani adalah proses pendidikan melalui aktivitas jasmani, permainan atau olahraga.

Dengan demikian maka dapat disimpulkan bahwa pendidikan jasmani merupakan serangkaian aktivitas jasmani ayau olahraga, bisa dalam bentuk permainan atau munkin juga salah satu dar cabang olahraga yang bukan bersifat permainan melalui aktivitas jasmani atau olahraga maka seorang siswa dapat, dibina sekaligus dibentuk.

Dikatakan pembentukan, karena memang akan terjadi proses pembiasan melalui seperangkat rangsangan terhadap kemampuan-kemampuan yang dimiliki siswa . Pendidikan jasmani di Sekolah Dasar harus bertujuan untuk mengembangkan keterampilah fisik siswa, juga mengembangkan karakter siswa secara bersamaan, dengan demikian pendidikan jasmani menekankan tercapainya sesuatu tujuan pendidikan. Tujuan Pendidikan jasmani di Sekolah Dasar menurut Depdiknas (2003:3) adalah "Untuk membantu siswa dalam mengembangkan dan meningkatkan pengetahuan(cognitive), keterampilan ( psy chomotor), sikap (affective), dan kebugaran Jasmani ( physical fitness) yang dalam proses pembelajarannya mengutamakan aktivitas jasmani dan pembinaan Pola Hidup Sehat.

Selanjutnya Depdiknas (2003:4) juga menjelaskan bahwa fungsi pendidikan jasmani di Sekolah dasar adalah sebagai berikut:

“a) Aspek organic antara lain: menjadikan fungsi system tubuh menjadio lebih baik, sehingga individu dapat memenuhi tuntutan lingkungan secara memadai serta memiliki landasan untuk mengembangkan keterampilan. b) Aspek neuromuscular antara lain: Meningkatkan keharmonisan fungsi saraf dan otot.c) aspek perceptual antara lain: Mengembangkan kemampuan menerima dan membedakan isyarat.d) aspek kognitif antara lain: mengembangkan kemampuan menemukan sesuatu, memahami memperoleh pengetahuan dan mengambil keputusan.e) aspek social antara lain : menyesuaikan diri dengan orang lain dan lingkumgan dimana berada , f) aspek emosional antara lain: mengembangkan respon positif terhadap aktivitas jasmani"

Bila tujuan dan fungsi penjas sudah tercapai, tentu pengetahuan, keterampilan, sikap dan kebugaran jasmani serta kemampuan motorik ( motor aability) siswa menjadi lebih baik, karena siswa kaya dengan kemampuan pengetahuan gerak yang banyak.Menurut Luthan (1988:96) kemampuan motorik adalah kesanggupan seseorang yang berkaitan dengan pelaksanaan dari peragaan suatu keterampilan yang relative melekat setelah masa kanak-kanak.

Kemampuan motorik adalah Salah satu aspek penting dalam pembelajaran pendidikan Jasmani. Karena kemampuan motorik merupakan dasar dalam mengembangkan keterampilan siswa-siswa dalam pembelajaran Penjas. Selain itu juga kemampuan motorik adalah salah satu tujuan dan fungsional potensi yang dimiliki siswa yang diperoleh dari pembelajarn pendidikan jasmani di sekolah dasar. Oleh sebab itu, salah satu indicator tercapai tidak nya tujuan dalam pembelajaran pendidiksn Jasmani di Sekolah Dasar tersebut dapat dilihat dari tingkat kemampuan Motorik Siswa.

Namun dari survey awal yang penulis lakukan di SD Negeri 11 Padang Barat, terlihat fenomena kemampuan motorik siswa masih rendah. Fenomena-fenomena ini terlihat seperti 1) rendahnya kemampuan siswa dalam mengembangkan keterampilan yang telah diudapat dalam pembelajaran pada pertemuan sebelumnya.2) rendahnya kemauan siswa dalam mengikuti gerakangerakan yang dilaksanakan dalam pembelajaran jasmani yang diajarkan guru sewaktu Praktek. 3)

Rendahnya pengetahuan siswa tentang keterampilan yang berhubungan dengan pembelajaran jasmani, seperti cara berawalan dalam lari, cara mengatur pernafasan dalam melakukan kegiatan renang, padahal telah diajarkan sebelumnya,4) Siswa-siswa kurang mengerti cara mengembangkan kekuatan dan daya tahan otot-otot, padahal sudah diberikan keterampilan tersebut oleh guru dalam 
pembelajaran sebelumnya , dan 5) masih adanya siswa-siswa yang kurang mengerti cara bermain dan mengembangkan jasmani yang sehat, seperti tidak mampu melaksanakan senam yang telah diajarkan.

Fenomena permasalahan diatas menunjukan bahwa kemampuan motorik siswa masih kurang baik. Oleh sebab itu perlunya upaya mengembangkan kemampuan motorik siswa agar menjadi lebih baik. Banyak factor yang mempengaruhi kemampuan motorik seseorang diantaranya: Seperti yang dilakukan oleh Gusril (2003:9) yaitu "Kesegaran Jasmani,Aktivitas bermain dan Status Gizi".

Disamping itu kemampuan Motorik juga dapat dipengaruhi oleh pengembangan model pembelajaran, kemampuan guru, persepsi orang tua siswa, factor lingkungan dan sebagainya juga dapat mempengaruhi kemampuan motorik siswa. Pada masa anak - anak disebut masa kreatif yaitu masa dalam rntangan kehidupan yang menentukan apakah anak - anak menjadi pencipta karaya gerak baru yang di dapat aktivitas bermain atau menjadi anak yang pasif atau gerak. Soemitro (1992:2) menjelaskan yang dimaksud dengan aktivitas bermain adalah: "suatu kegiatan belajar anak yang menyesuaikan diri yang dorongannya timbul langsung dalam diri setiap individu dengan menggunakan jalan fikiran.

Bila diperhatikan pertumbuhan anak menunjukan kepada perubahan kuantitas pada ukuran tubuh. Perkembangan menggambarkan perubahan kuantitas pada ukuran tubuh. Perkembangan menggambarkan perubahna fungsi. Perkembangan motorik mencerminkan perubahan diri anak dalam berinteraksi dengan lingkungan yang penuh tantangan secara efektif. Dengan demikian semua ini tentunya tergantung dengan kemampuan anak dalaam mengeksploirasi dan mengeksploitasi segala unsure - unsur yang bermanfaat baagi motoriknya.

\section{METODE}

Penelitian ini tergolong penelitian survey dengan menggunakan tekhnik analisis korelasional. Penelitian ini bertujuan untuk melihat hubungan antara dua variabel secara kuantitatif. Adapun variabel yang di hubungan dalam penelitian ini adalah aktivitas bermain sebagai variabel bebas dan kemampuan motorik sebagai variabel terikat. Penelitian ini akan dilaksanakan di Sekolah Dasar Negeri 11 Padang Barat, Kota Padang. Populasi dalam penelitian ini adalah siswa sekolah dasar negeri 11 padang barat, kota padang yang berjumlah sebanyak 180 orang dengan rincian 93 orang siswa putera dan 87 orang siswa puteri, yang tersebar pada kelas I sebnyak 34 orang, kelas II sebanyak 25 orang, kelas III sebnyak 24 orang, kelas IV sebnyak 36, kelas v sebnayak 29 orang kelas vI sebnyak 32 orang, untuk lebih jelasnya dapat dilihat pada table 1 berikut:

\begin{tabular}{cccc}
\multicolumn{4}{c}{ Tabel 1. Penyebaran Populasi } \\
\hline Kelas & Putera & Puteri & Jumlah \\
\hline I & 19 & 15 & 34 \\
II & 10 & 15 & 25 \\
III & 11 & 13 & 24 \\
IV & 20 & 16 & 36 \\
V & 15 & 14 & 29 \\
VI & 18 & 14 & 32 \\
jumlah & 93 & 87 & 180 \\
\hline
\end{tabular}

Sampel secara sederhan a diartikan sebagai bagian dari populasi yang akan dijadikan sebagai sumber data dalam suatu penelitian. Sampel alam penelitian ini diambil dalam menggunakan tekhnik purposive sampling yaitu "pengambilan sampel didasarkan pada maksud yang telah ditetapkan sebelumnya atau dengan pertimbangan pertimbangan tertentu "(yusuf, 2005:105). Maka sampel yang diambil dalam penelitian ini hanya siswa kelas v saja, dengan pertimbangan siswa kelas I ,II,III dan kelas IV belum begitu mengerti dan paham dengan tes yang akan dierikan untuk siswa kelas vI disibukan dengan les kegiatan pelajaran lain. Dengan demikian jumlah sampel dalam penelitian ini berjumlah sebanyak 24 orang dengan rincian 15 orang siswa putera dan 14 oarang siswa putri. 


\section{Instrument penelitian}

1) Alat ukur untuk aktivitas bermain

Tujuan pengukuran dan evaluasi menurut winarno (2006:36) Memperediksi tingkat kemampuan,megetahui kemajuan siswa, Mehevaluasi kurikulum dan megevaluasi efektivitas pegajaran. Berdasarkan kutipan tersebut jelaslah bahwa salah satu tujuan Pegukuran yaitu dapat melakukan pegelompokan kemampuan yang dimiliki siswa. Demikian dalam penelitian ini untuk megetahui pegelompokan siswadilihat dalam aktivitas bermainnya pada saat diluar Jam pelajaran sekolah.

Alat yang dapat dipakai untuk megukur aktivitas bermain siswa SD adalah insrument pegamatan denggan indicator seperti yang dikemukakan oleh patty (1992) yaitu: "'1) melibat imajinasi , 2) gerakan spotan,3) interaksi social, 4) kesenanggan dan 5) kerjasama" Selanjutnya idikator ini dikembangkan dan diberi penilaian seperti yang terlihat pada table 2 dibawah ini:

\section{Tabel 2. Variabel Tes Aktivitas Bermain}

\begin{tabular}{lll}
\hline \multicolumn{1}{c}{ Indikator } & \multicolumn{1}{c}{ Sub indicator } & Nilai (\%) \\
\hline a. imajinasi & a. mengembangkan kemampuan intelektual & a. $1-20$ \\
b. gerakan spontan & b. belajar menerima kemampuan orang lain & b. $1-20$ \\
c. interaksi sosial & c. komunikasi dengan orang alain & c. $1-20$ \\
d. kesenangan & d. kegembiraan dankebahagian anak dalam bermain & d. $1-20$ \\
e. kerjasama & e. wahana membawa anak untuk menaati suatu peraturan & e. $1-20$
\end{tabular}

2) Tes kemampuan motorik ( depdiknas, 2000-9-15)

a) Lebih cepat 30 meter, tujuan untuk mengukur kecepatan lari.pelaksanaan tes : 1) star dilakukan dengan star berdiri, 2) pada aba - aba "tes berdiri dengan salah satu ujung jari kakinya sedekat mungkin dengan garis star, 3) pada aba - aba "siap" tes siap untuk berlari, 4) pada aba - aba "ya" yang berlari secepatnya menempuh jarak 30 meter sampai melewati garis finish, 5) bersamaan dengan aba - aba "ya" stop watch dijalankan dan di hentikan pada saat tes mencapai garis finis, 6) setiap tes dilakukan 2 kali.

b) Baring duduk ( sit up) 30 detik, tes ini brtujuan untuk mengukur daya tahan otot - otot perut.pelaksanaan tes: 1) tes berbaring telentang di lantai, jari - jari kedua tangan bersilang selip di belakang kepala sebagai alas, kedua lengan merapat kelantai, kedua kaki terbuka.lebih kurang $30 \mathrm{~cm}$ dan kedua lutut ditekuk dengan sudut lebih kurang 90 derjat. 2) seorang berlutut idepan tes membantu menekan kedua kakinya untuk menjaga agar kedua tumit berhubungan dengan lantai, 3) dengan aba - aba "ya" tes berusaha duduk sampai lutut kedua sikunya dan kembali kesikap semula., 5) gerakan tersebut dilakukan berulang kali sebanyak mungkin selama 30 detik. Bersamaan dengan aba - aba "ya" stop watch di jalankan dan tepat pada detik 30 stop watch dimatikan, 6) setiap tes diberikan kesempatan 1 kali.

c) Lari bolak balik 4x10 meter, tujuannya adalah unutk mengukur kelincahan tes dalam mengunbah arah, pelaksanaan tes, 1) star dilakukan dengan star sendiri, pada aba - aba "bersedia" tes berdiri dengan salah satu ujung kaki sdekat mungkin dengan garis star, 2) pada aba - aba "siap" diberikan dan siap unu=tuk berlari dan aba - aba "ya" tes segera menuju garis finish bats untuk mengambil dan memindahkan balok pertama lingkaran yang berada di tempat garis star, 3) kembali lagi menuju garis batas untuk mengambil dan memindahkan balok kedua setengah yang berada ditempat garis star.

d) Loncat tegak (vertical jump), tujuan tes ini adalah unutk mengetahui daya ledak otot - otot tungkai, pelaksanaan tes: 1) papan berskala bergantung pada didnidng setingi raihan orang yang di tes selama melakukan tes tangan ditaburi serbuk kapur. Dan siap berdiri dibawah makam skala menghadap kesamping, 2) tangan yang akan dipkai menepuk papan skala diangkat tinggi - tinggi diatas dan ditempelkan skala sehingga bekas tangan yang diberi serbuk kapur meninggalkan bekas raihan jarinya 3)pada skala yang ada pada papan bersekala tersebut (titik 
a) tes mengambil sikap hendak mellompat tinggi - tinggi ke atas, 4) tes segera menepuk tinggi tinggi ke atas menepuk papan ssat berada dipuncak lompatan bekas tangan adalah titik $\mathrm{b}-$ selisih antara $\mathrm{a}-\mathrm{b}$ adalah prestasi tes.

G)Tekhnik anilisa data

Tekhnik analisi data yang digunakan dalam penelitian ini adlah menggunakan korelasi product moment bertujuan unutk membentuk hubngan antara variabel bebas $(\mathrm{x})$ terhadap variabel terikat (y) matematis model ini menurut Riduan (2005:99)

\section{HASIL DAN PEMBAHASAN \\ Hasil Penelitian}

Deskripsi data, uji persyaratan analisis hipotesis ( Normalitas, dan homogenitas ) uji hipotesis dan pembahasan terhadap hasil penelitian.

\section{Aktivitas bermain putera}

Dari hasil tes aktivitas bermain yang dilakukan terhadap 15 sampel, didapatkan skor tertinggi 83,00 dan skor terendah 46,00 sedangkan range ( jarak pengukuran ) 37,00. Berdasarkan data kelompok tersebut rata-rata hitung ( mean) 62,53 dan nilai tengah ( median) 65,00 nilai sering muncul ( mode ) 54.00, simpangan baku ( Standar deviasi ) 11.35. Selanjutnya distribusi kategori kemampuan motorik dapat dilihat pada tabel 3 dibawah ini:

Tabel 3. Distribusi Frekuensi Kategori Aktivitas bermain Putera

\begin{tabular}{clcc}
\hline Skor & Kategori & Fa & Fr \\
$>82$ & Baik Sekali & 1 & 6.67 \\
$71-82$ & Baik & 3 & 20.00 \\
$59-70$ & Sedang & 4 & 26.67 \\
$47-58$ & Kurang & 6 & 40.00 \\
$34-46$ & Kurang Sekali & 1 & 6.67 \\
& & 15 & 100 \\
\hline
\end{tabular}

Pada Tabel 3. Dari 15 orang sampel ternyata hanya 1 orang ( $6.67 \%$ ) yang memiliki kategori baik sekali ,dan 3 orang (20.00\% ). Memiliki kategori baik . Sedangkan untuk kategori sedang adalah sebanyak 4 orang (26.67) , 6 orang ( $40.00 \%$ ) memiliki kategori kurang sekali. Berdasarkan ujian pada skor yang telah ditemukan di atas rata-rata sebanyak 4 orang ( $26.67 \%$ ) dan skor dalam kelompok rata-rata 4 orang $(26.67 \%)$. Sedangkan untuk skor dibawah rata-rata berjumlah sebanyak 7 orang $(46.67 \%)$.

\section{Kemampuan motorik putera}

Dari hasil tes kamampuan motorik yang dilakukan terhdap 15 orang dan skor yang terendah 6 sedangkan range (jarak pengukuran) 9. berdasarkan data Kelompok tersebut rata-rata hitung ( mean ) 10. Dan nilai tengah ( Median ) 9, nilai sering muncul (mode) 7, Simpangan baku ( Standar deviasi )3.09. selanjutnya distribusi kategori kemampuan motorik siswa putera dapat dilihat pada tabel 4 dibawah ini:

Tabel 4. Distribusi Frekuensi Kategori Kemampuan Motorik Putera

\begin{tabular}{clcc}
\hline Skor & \multicolumn{1}{c}{ Kategori } & $\mathrm{Fa}$ & $\mathrm{Fr}$ \\
\hline $14-15$ & Baik Sekali & 2 & 13.33 \\
$12-13$ & Baik & 4 & 26.67 \\
$10-11$ & Sedang & 1 & 6.67 \\
$8-9$ & Kurang & 3 & 20.00 \\
$6-7$ & Kurang Sekali & 5 & 33.33 \\
& & 15 & 100 \\
\hline
\end{tabular}

Pada Tabel 4, dari 15 orang sampel 2 orang (13.33\%) memiliki kategori baik sekali dan 4 orang $(26,67 \%)$ memiliki kategori baik. Sedangkan 1 orang (6.67\%) memiliki kategori sedang dan 3 orang 
(20.00\%) memiliki kategori kurang dan 5 orang (33.33\%) sampel yang memiliki kategtori kurang sekali.

Berdasarkan pada skor tersebut dapat disimpulkan bahwa skor diatas rata-rata sebanyak 6 orang $(40 \%)$ dan skor dalam kelompok rata-rata 1 orang $(6.67 \%)$ sedangkan skor dibawah rata-rata berjumlah 8 orang $(53.33 \%)$.

\section{Aktivitas Bermain Puteri}

Dari hasil tes aktivitas bermain yang dilakukan terhadap 14 sampel siswa puteri, didapatkan skor tertinggi 83.00 dan skor terendah 48.00 sedangkan range ( Jarak pengukuran ) 35.00 berdasarkan data kelompok tersebut rata-rata hitung (mean) 64.36, dan nilai tengah (median) 63.50 nilai sering muncul (mode) 62.00. Simpanan baku ( Standar Deviasi ) 8.76 Selanjutnya distribusi kategori aktivitas bermain siswa puteri dapat dilihat table 5 berikut ini :

Tabel 5. Distribusi Frekuensi Kategori Aktivitas Bermain Siswa Puteri

\begin{tabular}{llll} 
Skor & Kategori & fa & Fr \\
\hline$>83$ & Baik Sekali & 1 & 7.14 \\
$72-82$ & Baik & 1 & 7.14 \\
$61-71$ & Sedang & 8 & 57.14 \\
$50-60$ & Kurang & 3 & 21.43 \\
$<49$ & Kurang Sekali & 1 & 7.14 \\
& & 14 & 100
\end{tabular}

Pada table 5 diatas dapat diuraikan bahwa dari 14 orang sampel siswa puteri, 1 orabg $(7.14 \%)$ memiliki kategori baik sekali,dan 1 orang $(7.14 \%)$ memiliki kategori baik . Sedangkan 8 orang (57.14\%) memiliki kategori sedang , 3 orang $(21.43 \%)$ memiliki klategori kurang sekali. Berdasarkan Skor tersebut disimpulkan bahwa sampel yang berada pada skor diatas rata-rata berjumlah 6 orang $(42.86 \%)$ dan skor dalam kelompok rata-rata 1 orang $(7.14 \%)$ sedangkan untuk skor dibawah rata-rata berjumlah 7 orang $(50 \%)$.

4. Kemampuan Motorik Puteri (Y)

Dari hasil Tes kemampuan Motorik yang dilakukan terhadap 14 orang siswa puteri sebagai samp[el dalam penelitian ini.didapatkan skor tertinggi 11.00 dan skor terendah 6.00 sedangkan rang( Jarak pengukuran) 5.00 .Berdasarkan data kelompok tersebut rata-rata hitung (mean ) 7.71, dan nilai tengah (median) 8.5 , nilai sering muncul (mode)6.00 simpanan baku ( Standar deviasi) 1.59. Selanjutnya distribusi kategori kamampuan motorik dapat dilihat table 6 pada halaman selanjutnya:

Tabel 6. Distribusi Frekuensi Kategori Kemampuan Motorik Siswa Puteri

\begin{tabular}{clcc}
\hline Skor & Kategori & fa & Fr \\
\hline$>10$ & Baik Sekali & 1 & 7.14 \\
$9-10$ & Baik & 3 & 21.43 \\
$7-8$ & Sedang & 6 & 42.86 \\
$5-6$ & Kurang & 4 & 28.57 \\
$0-4$ & Kurang Sekali & 0 & 0.00 \\
& & 14 & 100 \\
\hline
\end{tabular}

Pada Tabel 6 terlihat bahwa dari 14 orang sampel , 1 orang $(7.14 \%)$ memiliki kategori baik sekali, dan 3 orang $(21.43 \%)$ memiliki kategori baik. Sedangkan 6 orang ( $42.86 \%)$ memiliki kategori sedang dan 4 orang $(28.86 \%)$ memiliki kategori kurang dan tidak ada sampel yang memiliki kategori kurang. Berdasarkan pada skor tersebut diatas dapat disimpilkan bahwa skor diatas rata-rata berjumlah 4 orang $(28.57 \%)$ dan skor dalam kelompok rata-rata sebanyak 3 orang $(21.43 \%)$. Sedangkan skor dibawah rata-rata berjumlah 7 orang $(50 \%)$.

\section{Uji Hipotesis}

Hipotesis pertama yang diajukan dalam penelitian ini adalah Terdapat hubungan yang signifikan antara aktivitas bermain dengan kemampuan motorik siswa putera SD Negeri 11 Padang Barat. Untuk 
menguji hipotesis tersebut dilakukan analisis korelasi product moment Hasil analisis korelasi antara aktivitas bermain $(\mathrm{X})$ dengan kemampuan motorik putera $(\mathrm{Y})$ adalah $\mathrm{r}=0,77$ artinya semakin meningkat variabel $\mathrm{X}$, maka variabel $\mathrm{Y}$ meningkat. Untuk mengetahui berapa besar kontribusi variabel aktivitas bermain (X) terhadap kemampuan motorik (Y) digunakan $\mathrm{r}^{2}$ x $100 \%$ atau $0,77 \times 100 \%=$ $59,29 \%$. Artinya kontribusi variabel X terhadap Y adalah 59,29 sedangkan 40,71\% disebabkan oleh variabel lain.

Untuk menguji signifikan koefisien korelasi antara aktivitas bermain (X) dengan kemampuan motorik siswa putera (Y) dilakukan uji t. untuk lebih jelasnya hasil uji t tersebut dapat dilihat pada rangkuman di bawah ini:

Tabel 9. Rangkuman Uji signifikansi Koefisien Korelasi Antara X d Y Siswa Putera

\begin{tabular}{cccc}
\hline Variabel & $\mathbf{t}_{\text {hitung }}$ & $\mathbf{t}_{\text {tabel }}$ & Kesimpulan \\
$\mathrm{X}$ dan Y & 4,51 & 2,160 & Signifikan \\
\hline
\end{tabular}

Berdasarkan tabel 9 ternyata $t_{\text {hitung }}=4,51>\mathrm{t}_{\text {tabel }}=2.160$ Dengan demikian dapat disimpulan bahwa hipotesis yang diajukan terdapat hubungan yang signifikan antara aktivitas bermain dengan kemampuan motorik siswa putera SD Negeri 11 Padang Barat Kota Padang diterima kebenaran secara empiris.

Hipotesis kedua yang diajukan dalam penelitian ini adalah terdapat hubungan yang signifikan antara aktivitas bermain dengan kemampuan motorik siswa puteri SD Negeri 11 Padang Barat Kota Padang Untuk menguji hipotesis tersebut dilakukan analisis korelasi product moment. Hasil analisis korelasi antara aktivitas bermain $(\mathrm{X})$ dengan kemampuan motorik $(\mathrm{Y})$ adalah $\mathrm{r}=0,73$ artinya semakin meningkat variabel $\mathrm{X}$, maka variabel $\mathrm{Y}$ meningkat. Untuk mengetahui berapa besar kontribusi variabel aktivitas bermain $(\mathrm{X})$ terhadap kemampuan motorik $(\mathrm{Y})$ digunakan $\mathrm{r}^{2} \times 100 \%$ atau $0,73 \times 100 \%=$ $53,35 \%$. Artinya kontribusi variabel X terhadap Y adalah 53,35 sedangkan 46,65 disebabkan oleh variabel lain.

Untuk menguji signifikan koefisien korelasi antara aktivitas bermain (X) dengan kemampuan motorik siswa puteri (Y) dilakukan uji t. Untuk lebih jelasnya hasil uji t tersebut dapat dilihat rangkuman pada tabel 9 di halaman selanjutnya.

Tabel 10. Rangkuman Uji signifikansi Koefisien Korelasi Antara X denoan Y Siswa Puteri

\begin{tabular}{ccrc}
\hline Variabel & $\mathbf{t}_{\text {hitung }}$ & $\mathbf{t}_{\text {tabel }}$ & Kesimpulan \\
$\mathrm{X}$ dan Y & 3,72 & 2,179 & Signifikan \\
\hline
\end{tabular}

Berdasarkan tabel 10 ternyata $t_{\text {hitung }}=3.72>t_{\text {tabel }}=2.179$. Dengan demikian dapat disimpulan bahwa hipotesis yang diajukan $t$, terdapat hubungan yang signifikan antara aktivitas bermain dengan kemampuan motorik siswa puteri SD Negeri 11 Padang Barat Kota Padang diterima kebenaran secara empiris.

\section{Pembahasan}

Berdasarkan hasil pengujian hipotesis pertama yang diajukan dalam penelitian yaitu: terdapat hubungan yang signifikan antara aktivitas bermain dengan kemampuan motorik siswa putera SD Negeri 11 Padang Barat Kota Padang teruji kebenarannya secara empiris. Hal ini menunjukkan bahwa aktivitas bermain mempunyai hubungan yang berarti terhadap kemampuan motoriksiswa putera SD Negeri 11 Padang Barat. dilihat dari hasil koefisien korelasi antara aktivitas bermain (X) dengan kemampuan motorik (Y) hasilnya positif yaitu: 0,77 dan ini berarti jika aktivitas bermain (X) siswa meningkat, kemampuan motoriknya (Y) juga meningkat.

Selanjutnya berdasarkan kepada analisis koefisien korelasi determiansi yaitu untuk menentukan besar kontribusi variabel aktivitas bermain (X) terhadap variabel kemampuan motorik siswa putera (Y), adalah 59,29\% dan 40,71\% adalah variabel lain. Dengan demikian jelaslah bahwa aktivitas bermain mempunyai hubungan yang berarti dan memberikan sumbangan. Selanjutnya hasil pengujian hipotesis kedua yang diajukan dalam penelitian yaitu: terdapat hubungan yang signifikan antara 
aktivitas bermain dengan kemampuan motorik siswa puteri SD Negeri 11 Padang Barat Kota Padang teruji kebenarannya secara empiris.

Hal ini menunjukkan bahwa aktivitas bermain mempunyai hubungan berarti terhadap kemampuan motorik siswa puteri SD Negeri 11 Padang Barat. Dilihat dari hasil koefisien korelasi antara aktivitas bermain $(\mathrm{X})$ dengan kemampuan motorik siswa puteri( $\mathrm{Y})$ hasilnya positif yaitu $=0,73$ Dan ini berarti jika aktivitas bermain (X) siswa puteri meningkat, kemampuan motoriknya (Y) juga meningkat. Selanjutnya berdasarkan kepada analisis koefisien korelasi determiansi yaitu untuk menentukan besar kontribusi variabel aktivitas bermain (X) terhadap variabel kemampuan motorik siswa puteri (Y), adalah 53,35\% dan 46,65\% adalah didapat dari variabel lain.

Terjadinya hubungan yang signifikan antara variabel aktivitas bermain $(\mathrm{X})$ terhadap variabel kemampuan motorik siswa puteri (Y). Soemitro (1992.2) menjelaskan bahwa yang dimaksud dengan aktivitas bermain adalah: "suatu kegiatan belajar anak menyesuaikan diri yang dorongannya timbul langsung dalam diri setiap individu dengan menggunakan jalan fikiran dan seluruh jiwanya lepas dari lingkungan. Selanjutnya Sukintaka (2004:2) mengatakan aktivitas bermain yaitu: "kegiatan yang dilakukan dengan sukarela dan didasari oleh rasa senang untuk memperoleh kesenangan dari permainan itu".

Bila diperhatikan pertumbuhan anak rnenunjukkan kepada perubahan kuantitas dalam ukuran tubuh. Perkembangan menggambarkan perubahan dalam fungsi. Perkembangan motorik mencerminkan perubahan diri anak dalam berinteraksi dengan lingkungannya yang penuh tantangan secara efektif. Dengan demikian semua ini tentunya sangat tergantung pada kemampuan anak dalam mengeksplorasi dan mengeksploitasi segala unsur-unsur yang bermanfaat bagi motoriknya. Kiram (2000:5) mengartikan motorik adalah "suatu peristiwa laten yang meliputi keseluruhan proses-proses pengendalian dan pengaturan fungsi-fungsi organ tubuh baik secara fisiologis maupun secara psikis yang menyebabkan terjadinya suatu gerakan". Dalam hal ini erat kaitannya dengan aktivitas yang dilakukan siswa seperti aktivitas bermain.

\section{KESIMPULAN}

Berdasarkan pada hasil penelitian dan uraian temuan, tentang hubungan antara aktivitas bermain dengan kemampuan motorik siswasiswi SD Negeri 11 Padang Barat Kota Padang dapat disimpulkan. Terdapat hubungan yang signifikan antara aktivitas bermain dengan kemampuan motorik siswa putera SD Negeri 11 Padang Barat diterima kebenaran secara empiris. Terdapat hubungan yang signifikan antara aktivitas bermain dengan kemampuan motorik siswa puteri SD Negeri 11 Padang Barat diterima kebenaran secara empiris.

Berdasarkan kepada kesimpulan dalam penelitian ini, maka disarankan kepada Guru pendidikan jasmani olahraga dan kesehatan di Sekolah Dasar, dapat meningkatkan kemampuan motorik anak dalam pernbelajaran, sehingga aktivitas bermain anak akan lebih baik. Kelompok kerja guru pendidikan jasmani olahraga dan kesehatan di Kecamatan Padang Barat, agar dapat meningkatkan kemampuan motorik anak melalui pembelajaran Pendidikan Jasmani Olahraga dan kesehatan (PJOK).

Para orang tua agar memperhatikan dan memberikan kebebasan anak dalam beraktivitas bermain, karena anak seusia ini mereka belajar sambil bermain. Hal ini dapat memperkaya gerak sehingga hal ini dapat meningkatkan kemampuan motorik mereka.

\section{DAFTAR RUJUKAN}

Depdiknas, 2003. Tes Kesegaran Jasmani Indonesia Untuk Anak Umur 10-12 Tahun. Jakarta: Pusat Pengembangan Kualitas Jasmani. 
Depdiknas, 2003. Dasar-Dasar Kepelatihan Olahraga. Jakarta: Proyek Pendidikan Jasmani Luar Biasa.

Gusril, 2003. Faktor-Faktor Yang Mempengaruhi Kemampuan Motorik Siswa Sekolah Dasar Negeri Kodya Padang. Disertasi. Jakarta: Pascasarjana, UNJ.

Gusril, 2005. Model Pengembangan Motorik Siswa Sekolah Dasar. Padang: FlK-Universitas Negeri Padang.

Hadi, soetrisno, 1993. Metodologi Research. Jogjakarta: Andi Offset.

Harsono. 1988. Coaching Dan Aspek-Aspek Psiklogis Dalam Coaching. Jakarta: P2lptk.

Helms, Donald B Dan Jeffrey. Tuner.1981. Child Behavior. New York: Holt Rinehart And Winston.

Kiram, Yanuar. 1992. Belajar Motorik. Jakarta: Depdikbud.

Kiram, Yanuar.2000. Belajar Motorik. Padang: FIK Universitas Negeri Padang.

Lutan, Rusli. 2002. Mengajar Untuk Belajar Dalam Pendidikan Jasmani. Bandung: FPOK Universitas Pendidikan Indonesia.

Luthan, Rusli. 1988. Belajar Keterampilan Motorik: Pengantar Teori Dan Metode. Jakarta. Depdikbud.

Magil, Richard. 1980. Motor Learning Concepts Aplication. Dubuque: IOWA, C. Brown. Company Publisher.

Riduwan, 2005. Belajar Mudah Penelitian Untuk Guru-Karyawan Dan Peneliti Pemula. Jakarta: Alfabeta.

Soemintro, 1992. Permainan Kecil. Jakarta: Depdikbud.

Soetjiningsih, 1995. Tumbuh Kembang Anak. Surabaya: Universitas Airlangga.

Sukintaka, 1992. Teori Bermain Untuk Penjaskes. Jakarta: Depdikbud.

Sukintaka, 2004. Teori Pendidikan Jasmani: Filosofi Pembelajaran Dan Masa Depan. Bandung: Nuansa.

Wahjoedi. 2001. Landasan Evaluasi Pendidikan Jasmani. Jakarta: PT. Raja Grafindo Persada.

Winarno. 2006. Tes Keterampilan Olahraga. Malang: Fakultas Ilmu Pendidikan: Universitas Negeri Malang. 